\title{
Airway remodelling in asthma: From benchside to clinical practice
}

\author{
Céline Bergeron MD FRCPC MSc ${ }^{1}$, Meri K Tulic PhD², Qutayba Hamid MD PhD
}

C Bergeron, MK Tulic, Q Hamid. Airway remodelling in asthma: From benchside to clinical practice. Can Respir J 2010;17(4): e85-e94.

\begin{abstract}
Airway remodelling refers to the structural changes that occur in both large and small airways relevant to miscellaneous diseases including asthma. In asthma, airway structural changes include subepithelial fibrosis, increased smooth muscle mass, gland enlargement, neovascularization and epithelial alterations. Although controversial, airway remodelling is commonly attributed to an underlying chronic inflammatory process. These remodelling changes contribute to thickening of airway walls and, consequently, lead to airway narrowing, bronchial hyper-responsiveness, airway edema and mucous hypersecretion. Airway remodelling is associated with poor clinical outcomes among asthmatic patients. Early diagnosis and prevention of airway remodelling has the potential to decrease disease severity, improve control and prevent disease expression. The relationship between structural changes and clinical and functional abnormalities clearly deserves further investigation. The present review briefly describes the characteristic features of airway remodelling observed in asthma, its clinical consequences and relevance for physicians, and its modulation by therapeutic approaches used in the treatment of asthmatic patients.
\end{abstract}

Key Words: Allergy; Asthma; Remodelling; Rhinitis

\section{CLINICAL RELEVANCE OF AIRWAY REMODELLING IN ASTHMA}

Airway remodelling in asthma was first described in 1922 by Hubert and Koessler in cases of fatal asthma (1). Since then, airway remodelling has been documented in all degrees of asthma severity, and in both large and small airways (2). Airway remodelling refers to the structural changes in the airways of asthmatic subjects not seen in healthy subjects. Structural changes include the loss of epithelial integrity (3), thickening of basement membrane (4), subepithelial fibrosis (5), goblet cell and submucosal gland enlargement $(6,7)$, increased smooth muscle mass (6), decreased cartilage integrity (8) and increased airway vascularity $(9,10)$. Figure 1 shows the

\author{
Remodelage des voies respiratoires dans l'asthme : \\ De la recherche à la pratique clinique
}

Le remodelage des voies respiratoires fait référence aux changements structuraux qui affectent les voies respiratoires, de gros et de petit volume, en lien avec diverses maladies, dont l'asthme. Dans l'asthme, les changements structuraux des voies respiratoires incluent la fibrose sous-épithéliale, l'augmentation de la masse musculaire lisse, l'hypertrophie glandulaire, la néovascularisation et des altérations épithéliales. Bien qu'il ne fasse pas l'unanimité, le remodelage des voies respiratoires est souvent attribué à un processus inflammatoire chronique sous-jacent. Ces anomalies contribuent à l'épaississement de la paroi des voies respiratoires et par conséquent, à un rétrécissement de leur calibre, à une hyperréactivité bronchique, à l'œedème et à l'hypersécrétion. Le remodelage des voies respiratoires est associé à de piètres paramètres cliniques chez les patients asthmatiques. Le dépistage précoce et la prévention du remodelage des voies respiratoires peuvent atténuer la gravité de la maladie, en améliorer la maîtrise et en prévenir l'expression. Le lien entre les changements structuraux et les anomalies cliniques et fonctionnelles mérite clairement qu'on s'y attarde davantage. La présente synthèse décrit brièvement les caractéristiques clés du remodelage des voies respiratoires observées dans l'asthme, leurs conséquences cliniques, leur portée sur la pratique médicale et leur modulation au moyen des approches thérapeutiques antiasthmatiques. features of remodelling in asthma. It is believed that these changes largely stem from an ongoing chronic inflammatory process that involves activation of inflammatory cells including $\mathrm{CD}^{+} \mathrm{T}$ cells, eosinophils, neutrophils and mast cells (11-15). The duration of asthma has been associated with reduced lung function, increased airway hyper-responsiveness (AHR) and asthma symptoms, as well as greater use of medications $(5,16,17)$. The remodelling process has been proposed to explain these features. An overview of the clinical consequences of airway remodelling in asthma is presented in Figure 2.

\section{Epithelial alteration and clinical impact}

Epithelial alterations in asthma include epithelial shedding, destruction of ciliated cells, goblet cell hyperplasia, upregulation

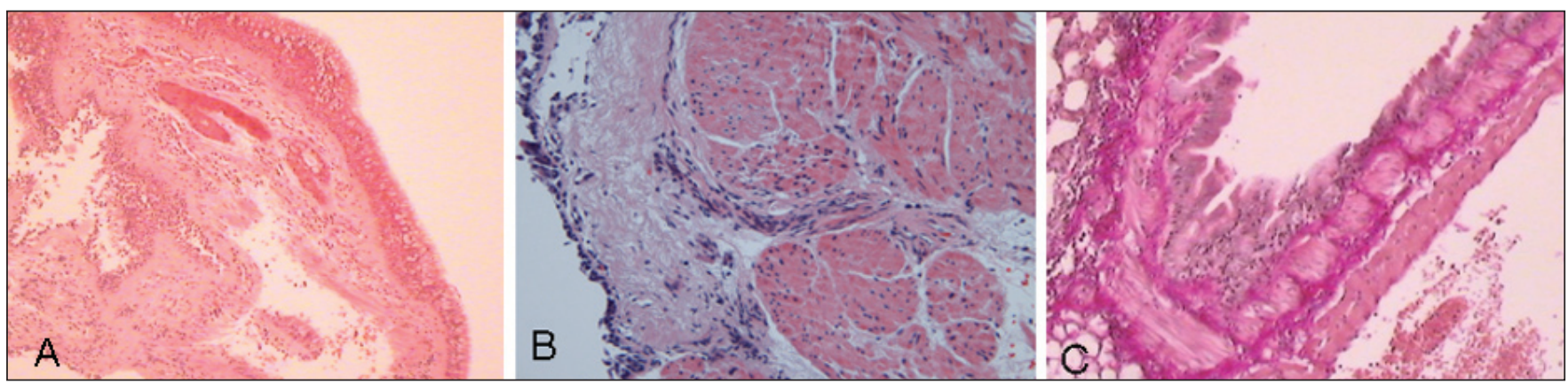

Figure 1) A Hematoxylin and eosin-stained endobronchial biopsy sample from an asthmatic subject showing goblet cell hyperplasia (original magnification $\times 40$ ). B Hematoxylin and eosin-stained endobronchial biopsy sample from an asthmatic subject showing extensive total subepithelial fibrosis and increased smooth muscle mass (original magnification $\times 200$ ). C Lung biopsy sample of a small airway from an asthmatic subject showing increased smooth muscle mass and submucosal fibrosis (original magnification $\times 200$ )

\footnotetext{
${ }^{1}$ Hotel-Dieu Hospital, Centre Hospitalier de l'Université de Montréal, University of Montreal, Montreal, Quebec; ${ }^{2}$ Division of Cell Biology, Telethon Institute for Child Health Research, Centre for Child Health Research, Perth, Australia; ${ }^{3}$ Meakins-Christie Laboratories,

McGill University, Montreal, Quebec

Correspondence: Dr Qutayba Hamid, Meakins-Christie Laboratories, McGill University, 3626 St Urbain Street, Montreal, Quebec H2X 2 P2.

Telephone 514-398-3864 ext 00143, fax 514-398-7483, e-mail qutayba.hamid@mcgill.ca
} 


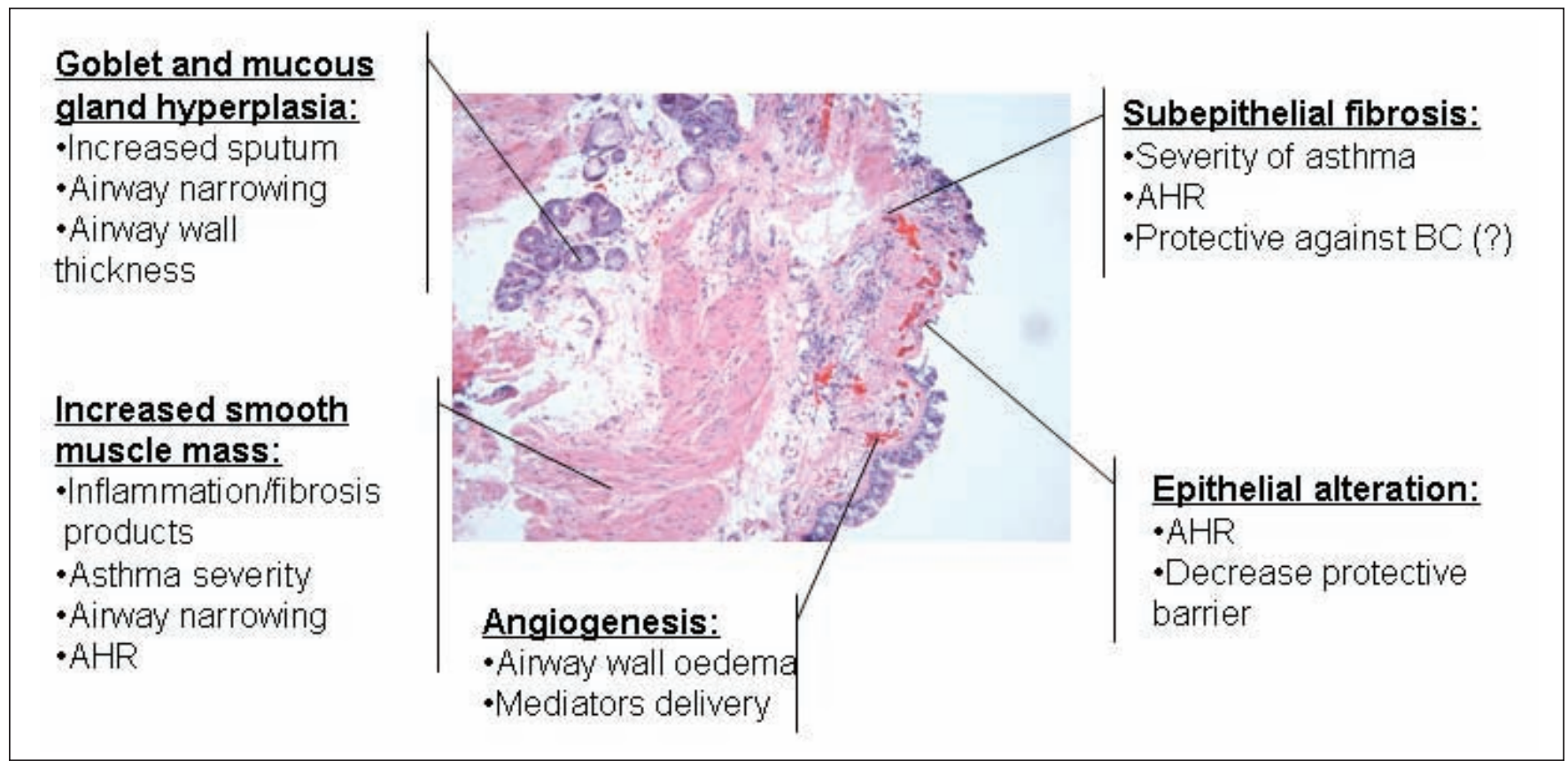

Figure 2) Main airway remodelling features observed in endobronchial biopsies from a severe asthmatic subject. Clinical consequences of each remodelling feature are reported. AHR Airway hyper-responsiveness; BC Bronchoconstriction

of growth factor release, and overexpression of receptors such as epidermal growth factor receptors $(3,6,18-22)$. Clinically, the extent of epithelial injury is correlated with $\operatorname{AHR}(17,23)$, clearly suggesting that the degree of epithelial loss and/or turnover is related to asthma development and severity. The intact airway epithelium normally provides a physical protective barrier against inhaled small particles such as allergens. The loss of epithelial surface and the resultant denudation of the basement membrane may decrease this protective effect and increase the propensity for allergic insult to the airway.

\section{Subepithelial fibrosis and clinical impact}

A second important feature of airway remodelling is subepithelial fibrosis, which has consistently been reported in all severities of asthma $(5,17)$, in subjects with atopic rhinitis $(24,25)$ and even in children with asthma that is difficult to treat $(26,27)$. Subepithelial fibrosis occurs in the lamina reticularis just below the basement membrane, resulting in thickening of the basement membrane just below the epithelium. Fibrosis is a result of increased deposition and decreased degradation of extracellular matrix (ECM) proteins $(4,28-31)$ by fibroblasts. Intrinsic differences are observed in airway fibroblasts of asthmatic patients compared with nonasthmatic patients (32). Asthmatic airway fibroblasts promote fibrosis though a higher ratio of tissue inhibitor of metalloproteinase (TIMP)-2 to matrix metalloproteinase (MMP)-2, resulting in less ECM degradation.

Clinical correlations have been found between the severity of asthma, AHR or attack score and subepithelial deposition of collagen types I and III in the airways (33-35). Subepithelial fibrosis has been associated with asthma severity and, in severe asthma, increased airway wall thickness is observed (36). Proteoglycan deposition in the ECM and bronchial fibroblast production of proteoglycans also correlate with AHR in asthmatic subjects $(28,37)$. An imbalance between ECM protein production and degradation has also been demonstrated in the airways of asthmatic individuals. The level of proteases and antiproteases may favour a profibrotic balance. Interstitial cells, macrophages and neutrophils are the major sources of proteases and antiproteases. MMPs are a family of proteases implicated in collagen degradation. MMP-2, MMP-3, MMP-8 and MMP-9 are MMPs related to asthma (38-41). Among these, MMP-9 levels are reported to be significantly higher in the sputum of asthmatic patients than in control subjects (40). MMPs are implicated in airway inflammation through their influence on eosinophil trafficking (42) and in airway remodelling, not only by matrix reorganization but also by their effects on angiogenesis (43) and smooth muscle hyperplasia $(44,45)$. Elevated sputum MMP-9 levels are associated with a fall in forced expiratory volume in $1 \mathrm{~s}\left(\mathrm{FEV}_{1}\right)$ following allergen challenge and is linked to asthma severity $(42,46)$. Levels of MMP-8 in bronchoalveolar lavage (BAL) samples are inversely correlated with $\mathrm{FEV}_{1}$ in asthmatic patients (39).

\section{Increased smooth muscle mass and clinical impact}

Respiratory airway smooth muscle is the critical effector cell modulating airway tone. In asthmatic airways, the smooth muscle mass is increased due to a coordinated increase in the size (hypertrophy) and number (hyperplasia) of airway smooth muscle cells. Importantly, asthmatic smooth muscle cells not only take on the secretory and proliferative phenotype but can also migrate to the subepithelial area of the asthmatic airways $(6,47,48)$. Smooth muscle cells are known to actively participate in the inflammatory and remodelling processes through their release of proinflammatory cytokines, chemokines and ECM proteins (49-51), and therefore, may contribute to the pathogenesis of asthma. Migration of smooth muscle cells is a recently described feature of airway remodelling. We have shown (48) that chemokines have the ability to induce human airway smooth muscle cell migration and to increase their contractility in vitro, implicating another avenue that may 
significantly contribute to the overall airflow obstruction in these patients. The importance of smooth muscle mass has been correlated with asthma severity (52).

Goblet cell and mucous gland hyperplasia, and clinical impact Goblet cell hyperplasia and submucosal gland hyperplasia are seen in the airways of asthmatic adults and children, and are a feature particularly evident in fatal asthma $(6,7,27)$. Functional consequences of these abnormalities mostly result in increased sputum production, airway narrowing due to sputum secretion and increased airway wall thickness (6).

Angiogenesis and clinical impact

Vascular alterations include increased size of airway wall vessels and angiogenesis (9). Changes in the airway wall microvasculature can contribute to airway wall edema and result from angiogenesis. Increased airway vascularity is seen in asthma $(9,10)$ in association with a greater expression of vascular endothelial growth factor (53). Clinical consequences of airway wall angiogenesis include reduced airway calibre via airway wall edema, and increased inflammatory and remodelling mediator delivery into the airway wall, subsequently having an influence on structural and inflammatory cells.

Loss of cartilage integrity and clinical impact

Cartilage is an important determinant of airway wall stiffness and integrity. Decreased cartilage volume and increased cartilage proteoglycan degradation are seen in the airways of asthmatic patients (8). Reduced cartilage integrity may result in a more powerful bronchoconstriction as a consequence of load reduction on airway smooth muscle bundles. Cartilage degradation can contribute to chronic airway obstruction and enable more powerful bronchoconstriction for a given degree of airway smooth muscle contraction (54).

\section{Inflammation and clinical impact}

The airways of asthmatic individuals are characterized by a T-helper cell (Th)2 profile inflammation consisting of an overabundance of eosinophils, mast cells and Th2 lymphocytes. These inflammatory cells release mediators that trigger bronchoconstriction, mucous secretion and, possibly, remodelling. The number of infiltrating leukocytes, such as mast cells, eosinophils, $\mathrm{CD}^{+}$and CD45 ${ }^{+} \mathrm{T}$ cells, correlates with AHR in patients treated with inhaled corticosteroids (ICS) (55). The inflammatory mediators that drive this process include the Th2 cytokines interleukin (IL)-4, IL-5, IL-9 and IL-13, transforming growth factor (TGF)-beta, granulocyte/macrophage colonystimulating factor (GM-CSF), lipid mediators and histamine. Some of these mediators, such as TGF-beta, IL-11 and IL-17 $(33,56,57)$, have potent remodelling properties (Figure 3$)$. Histamine was recently proposed to participate in airway remodelling through increased fibroblast proliferation and connective tissue growth factor production (58).

\section{TOOLS USED TO MEASURE AIRWAY REMODELLING}

Airway remodelling is clinically defined as persistent airflow obstruction despite aggressive anti-inflammatory therapies. The standard assessment of remodelling is obtained by surgical lung specimens or airway tissues sampled through flexible bronchoscopy. Although flexible bronchoscopy is a minimally

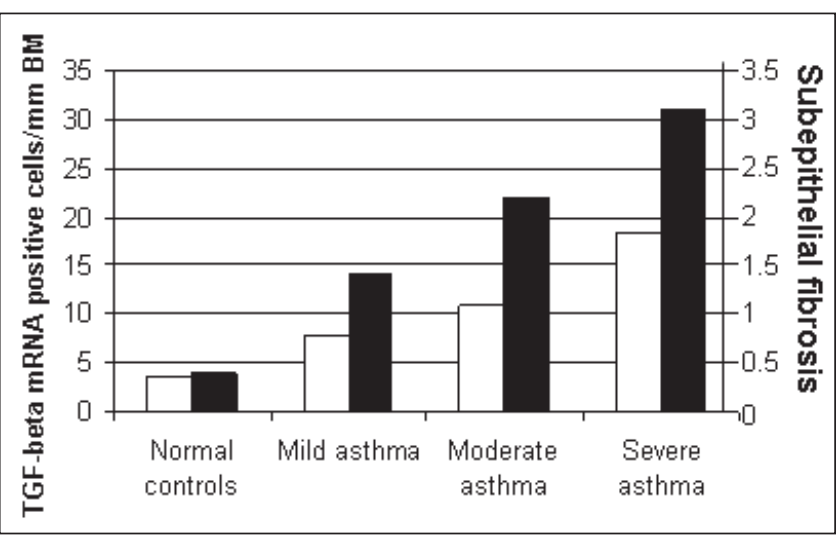

Figure 3) Transforming growth factor (TGF)-beta messenger RNA (mRNA) expression and subepithelial fibrosis increase with asthma severity. TGF-beta expression is correlated with subepithelial fibrosis. Subepithelial fibrosis was measured by collagen I and III expression levels. Airway biopsies were used to detect TGF-beta and collagen expression. BM Basement membrane. Modified from Minshall et al (132)

invasive technique that requires specialist expertise, tools have been developed to bypass biopsy sampling. Among these tools, indirect analysis of blood and urine, and sputum remodelling markers have been developed, from which only clues to the ongoing fibrotic process can be gained. Whether fluid variations in remodelling markers have significant consequences in the diseased airway walls remains unknown. Other alternative tools, including high-resolution computed tomography, endobronchial ultrasound and lung function measurement, can also be used as screening tools. However, modulation of airway remodelling requires confirmation with airway wall specimens. Clinicians should consider airway remodelling in all subjects with asthma and rhinitis. Fixed airflow obstruction is regarded to be a late and irreversible manifestation of airway remodelling. For this reason, even without reliable and easily available tools to confirm the presence of remodelling, clinicians should adjust allergic airway therapy to prevent development or worsening of airway and tissue remodelling. The tools to detect airway remodelling were reviewed in detail by Bergeron et al (59).

\section{APPROACHES TO AIRWAY REMODELLING IN CLINICAL PRACTICE}

Effect of airway remodelling on lung function decline

According to previous observations (17,18, 21-52), structural alterations combined with the inflammatory process appear to be related to the magnitude of functional abnormalities in asthma. As previously described, airway remodelling has significant effects on lung function, including AHR and airway obstruction, and is believed to be responsible for the chronicity of asthma. Conversely, the long-term influence of airway remodelling remains controversial. The Childhood Asthma Management Program (CAMP) study (16) demonstrated an association between asthma duration and reduced lung function, higher AHR, greater asthma symptomatology and increased use of beta-2 agonists. Furthermore, Lange et al (60) reported an accelerated decline of lung function in asthmatic compared with nonasthmatic subjects. These observations may be related to airway remodelling. Two studies $(26,27)$ 
compared bronchial biopsies from children with difficult to treat asthma with those from adult asthmatic patients and found no difference in the extent of reticular basement membrane thickness. Furthermore, no correlations were found with respect to age, symptom duration, lung function or eosinophilic inflammation. The long-term effects of airway remodelling are still unknown and more studies are needed to determine its role in permanently altering lung function in asthma. The identification of airway remodelling in children confirms that airway remodelling occurs early in asthma and that it may be a precursor to this debilitating chronic disease.

\section{Prevention of airway remodelling}

A 23-year longitudinal study (61) revealed that the incidence of asthma and allergic rhinitis increases with age. Patients with ongoing allergic rhinitis have a three-fold greater chance of developing asthma. Interestingly, relief of rhinitis symptoms over time correlates with concurrent improvement in asthma symptoms. Subjects with more severe and persistent rhinitis are at higher risk of developing asthma (62). This association was also found in nonatopic subjects in whom perennial rhinitis was a risk factor for developing asthma (63). An interesting study by Chakir et al (24) reported structural remodelling abnormalities (subepithelial fibrosis and increased myofibroblasts) in the lower airways of allergic rhinitic subjects without asthma. Moreover, Laprise et al (64) demonstrated epithelial shedding, focal subepithelial fibrosis and lower airway inflammation in asymptomatic atopic subjects with AHR. In these atopic subjects, asymptomatic AHR was predictive of asthma development; the authors suggested it was related to early structural changes in their airways (65).

The effective treatment of rhinitis has been demonstrated to significantly improve asthma control. Intranasal corticosteroids significantly improve AHR to methacholine (66) and prevent increased bronchial responsiveness associated with seasonal pollen exposure (67). Other rhinitis treatments, such as montelukast and antihistamines, have also been reported to improve asthma symptoms when used in rhinitic subjects (68). Immunotherapy is reserved for moderate to severe allergic rhinitic subjects. Immunotherapy reduces inflammatory cell recruitment and activation, as well as the secretion of mediators (69). In a group of allergic rhinitis subjects with asthma, immunotherapy improved methacholine hyper-reactivity and quality of life, while reducing seasonal asthma symptoms (70). Reducing allergen sensitivity leads not only to relief of rhinitis but also helps control asthma, although less effectively. The beneficial effects of rhinitis treatment on AHR or asthma outcomes are believed to occur through the reduction of airway inflammation. Whether this reduced inflammation leads to diminished airway remodelling and less asthma expression is still unknown.

\section{Effect of current asthma treatment modalities on airway remodelling}

Corticosteroids: Control of persistent asthma can be achieved with early treatment and maintenance therapy with ICS (71). ICS have the potential to influence remodelling of individual structural cells. Corticosteroids have been reported to modulate inflammation (72) and induce apoptosis in airway epithelial cells (73), which may contribute to epithelial shedding. The effect of corticosteroids on fibroblasts has not been adequately studied. Proliferation and inflammatory mediators released in human lung fibroblasts can be reduced by use of corticosteroids (74) and by combining corticosteroids with beta-2 agonists (75). Some studies (76-78) reported that corticosteroids decrease smooth muscle cell proliferation but are less effective in modulating the synthesis of ECM proteins and cytokines in smooth muscle cells. The antiproliferative effect of corticosteroids can, therefore, benefit asthmatic patients by reducing smooth muscle mass reduction if effective in vivo.

The effect of ICS treatment in asthma has been well studied using endobronchial biopsies. Both positive and neutral effectiveness on remodelling has been described. ICS decrease mucus (79) and tenascin (a matrix proteoglyan) (29) production in the airways of patients with chronic asthma. Subepithelial fibrosis is a major histological feature of asthma that has significant clinical consequences. A number of studies reported no change in basement membrane thickness following long-term (up to 10 years [80]) or short-term (eight weeks [81]) use of ICS. However, others (82-85) have demonstrated a modest decrease in basement membrane thickness after treatment lasting six weeks to two years. Furthermore, a decrease in reticular basement membrane thickness was observed in subjects receiving budesonide $800 \mu \mathrm{g} /$ day for two years (86), implying that ICS may be effective in reducing reticular basement membrane thickness when used over a long period of time and at a higher dose. In a group of moderate to severe asthmatic subjects in Quebec, no significant differences were seen in type I or type III collagen, or TGF-beta immunoreactivity after a two-week course of oral corticosteroids (57). The lack of ability of corticosteroids to inhibit TGF-beta expression may be responsible for persistent and ongoing fibrosis seen in this group of patients. It may be possible that the corticosteroid dose was too low or too short in duration for any effect to occur.

It is known that an imbalance between MMPs and antiproteases, such as TIMP, can cause fibrosis in the lungs. For this reason, various studies addressing the effects of corticosteroids on MMP/TIMP balance $(84,87)$ failed to draw the same conclusion. In subjects with mild asthma, corticosteroids had no effect on elevated MMP-9/TIMP-1 ratio or MMP-9 activity in sputum following allergen challenge (87), or on macrophage release of MMP-9 in asthmatic subjects (88).

ICS form the basis of asthma therapy and are currently the most effective way to control airway inflammation $(81,83,89$. 92). An eight-week treatment with ICS is sufficient to improve the provocative concentration inducing a $20 \%$ decrease in $\mathrm{FEV}_{1}$ by 1.85 -fold in patients with long-standing asthma (81). Ward et al (85) reported that the variability in AHR can be explained, in part, by the thickness of the reticular membrane, and the number of BAL epithelial cells and eosinophils. Part of the improvement in AHR produced by ICS can be attributed to early changes in inflammation, but a progressive and larger improvement was associated with subsequent changes in airway remodelling. ICS have limited effectiveness in improving reduced lung function in asthmatic patients $(93,94)$, with greater success if therapy is started early after asthma diagnosis (95). However, the CAMP study (16) reported no significant, long-term prevention of declining lung function in children treated with ICS presenting with mild to moderate asthma (96). Despite suggestions that ICS may influence remodelling through their anti-inflammatory effects, corticosteroids seem 
to have little, if any, effect on airway remodelling. This is supported in the study by Chakir et al (57), who documented failure of corticosteroids to decrease collagen I and III deposition in the lungs of asthmatic subjects. However, they suggested that this phenomenon may be due to persistently elevated TGF-beta expression in asthmatic tissue (Table 1).

Antileukotrienes: Montelukast, a cysteinyl leukotriene 1 (CysLT1) receptor antagonist is commonly used in asthma therapy as an add-on treatment. It has also been recently approved for the treatment of allergic rhinitis and exerciseinduced asthma. In a clinical study (97), asthmatic patients with nasal polyposis treated with montelukast experienced a $70 \%$ improvement in nasal symptoms and a $60 \%$ to $90 \%$ improvement in clinical asthma scores. Montelukast decreases sputum eosinophils after allergen challenge in asthmatic subjects (98). In addition to their anti-inflammatory effects, CysLT antagonists may play an important role in the pathogenesis of airway remodelling. Montelukast has been shown to significantly inhibit ovalbumin-induced airway smooth muscle hyperplasia, mucus gland hyperplasia and subepithelial fibrosis in sensitized mice $(99,100)$. A recent study (101) reported a decreased lymphocyte and myofibroblast count in the airways of asthmatic subjects after only eight weeks of montelukast treatment. Evidence from these animal and human studies indicate that antileukotrienes may prevent airway remodelling at the level of goblet and smooth muscle cell hyperplasia, and subepithelial fibrosis. However, long-term studies are needed to confirm the clinical outcomes of the antiremodelling effect of CysLT1 receptor antagonists in asthmatic patients (Table 1).

Anti-immunoglobulin E: Treatment with anti-immunoglobulin (Ig) E reduces blood IgE, decreases asthma symptoms and corticosteroid use but has little effect on airway lung function (102). Treatment with anti-IgE (eg, omalizumab) significantly reduced both sputum and tissue eosinophilia as well as $\mathrm{IgE}$ positive $T$ and B cells without any effect on AHR in asthmatic patients with mild but persistent disease (103). In addition, anti-IgE treatment has been shown to reduce levels of the circulating Th2 cytokines IL-5 and IL-13, and improve lung function in subjects with moderate to severe allergic asthma requiring daily administration of corticosteroids (104). Currently, little effect of anti-IgE treatment on the airway remodelling process has been reported.

Beta-adrenoreceptor agonists and theophylline: Beta- 2 agonists reduce airway muscular tone and improve expiratory flows. Although there is little evidence that beta- 2 agonists affect airway remodelling, Orsida et al (105) have shown that addition of salmeterol in symptomatic asthmatic patients (who are already taking ICS) can effectively reduce the number of vessels in their lamina propria after combined treatment when compared with patients treated with corticosteroids alone. Regarding theophylline, although an immunomodulatory effect has been suggested (106), there is no evidence supporting its influence on airway remodelling (Table 1).

\section{Therapies under investigation}

The inflammatory process remains the primary target of new drugs used in the future prevention and treatment of asthma. Current therapies are not designed to specifically treat the underlying remodelling process. Some agents, such as the CpG oligonucleotides or Bacille Calmette-Guérin vaccines,
TABLE 1

Overall estimate of the significance of drugs on asthma-related changes

\begin{tabular}{|c|c|c|c|}
\hline Pathological change & $\begin{array}{c}\text { Inhaled } \\
\text { corticosteroids }\end{array}$ & $\begin{array}{l}\text { Leukotriene } \\
\text { antagonists }\end{array}$ & $\begin{array}{l}\text { Long-acting } \\
\text { beta-agonists }\end{array}$ \\
\hline Mucous gland hyperplasia & $++?$ & $++?$ & $-?$ \\
\hline $\begin{array}{l}\text { Subepithelial collagen } \\
\text { deposition }\end{array}$ & +- & $+1-$ & - \\
\hline Angiogenesis & ++ & ++ & ++ \\
\hline Smooth muscle increased & $++?$ & ++ & $+?$ \\
\hline Epithelial alteration & +++ & $++?$ & - \\
\hline
\end{tabular}

Levels of evidence: - None; +- Little or none; + Mild; ++ Moderate; +++ Significant; ? Uncertain

are believed to be capable of switching the immune response from a Th2 to a Th1 profile (107). IL-5 antibodies target eosinophil-mediated inflammation, while rapamycin, a macrolide analogue, has immunosuppressive effects and may influence inflammation and remodelling in experimental mouse models of asthma (108). Selective phosphodiesterase (PDE) inhibitors, through their breakdown of intracellular cyclic adenosine monophosphate, have been reported to have bronchodilatory, anti-inflammatory and potential antiremodelling properties (109). Nonpharmacological approaches such as bronchothermoplasty, which is still in the experimental stage, have been shown to reduce the capacity of airway smooth muscle to contract (110,111-113).

Anticytokines: Soluble recombinant human IL-4 receptor has been used in human subjects in a clinical setting and appears to have similar effectiveness as ICS (114). Unfortunately, no data are available addressing its effect on airway remodelling. IL-4 receptor antagonists inhibit airway inflammation and AHR in animal models of asthma $(115,116)$. Moreover, monoclonal antibodies directed against IL-5 were shown to be effective in reducing the deposition of ECM proteins (tenascin, lumican and procollagen) in the basement membrane of mild asthmatic patients (108), and reducing blood and sputum eosinophilia in humans (117). Prevention of subepithelial fibrosis with anti-IL-5 treatment has been reported in a mouse model of asthma (118). Collectively, these data suggest that therapies directed toward blocking or neutralizing proinflammatory type 2 cytokines may be beneficial in preventing or perhaps reversing airway remodelling in asthmatic patients.

$\mathrm{CpG}$ : Because airway inflammation in asthma is considered to be under the control of Th2 lymphocytes, new therapeutic interventions that may reverse the Th2 pattern have been conceived. Bacterial DNA, particulary the $\mathrm{CpG}$ motifs, promote a Th1 immune response in animal models (107). Synthesized CpG oligonucleotides, known as immunostimulatory DNA sequences, are currently under investigation and have been shown to decrease the nasal inflammatory response in subjects with allergic rhinitis (119). Supporting studies in murine models $(107,120)$ showed that $\mathrm{CpG}$ treatment effectively abolished airway eosinophilia, IL-5, IL-4, IL-13 and GM-CSF production and increased interferon-gamma release. CpGoligonucleotide treatment induces a Th1 response through the activation of macrophages and dendritic cells, resulting in increased IL-12 production. This increase leads to a higher interferon-gamma/IL-4 ratio, which drives the immune response toward a Th1 profile. In addition, immunostimulatory DNA 
sequence treatment has been shown to reduce subepithelial fibrosis and goblet cell hyperplasia in both mouse and monkey models of asthma $(121,122)$. The ability of $\mathrm{CpG}$ oligonucleotides to drive the immune response from a Th2 to Th1 phenotype may, in part, contribute to its effectiveness in the fibrotic process in the lungs.

PDE inhibitors: PDE inhibitors may be a therapeutic option in asthma treatment because they increase intracellular concentrations of cyclic adenosine monophosphate, which has both bronchodilatory and anti-inflammatory effects on inflammatory cells involved in the pathogenesis of asthma. A new thalidomide analogue (a potent inhibitor of two main PDE isotypes in the lungs - PDE4 and PDE5) has been shown to be as effective as dexamethasone in inhibiting inflammatory changes in airways, and preventing parenchyma and airway remodelling in a murine model of chronic asthma (123). A PDE3 inhibitor (siguazodan) has been shown to reduce in vitro proliferation of human airway smooth muscle cells (109), while the PDE4 inhibitor (roflumilast) reduced inflammation, subepithelial collagen deposition and thickening of airway epithelium in a murine asthma model (124).

Rapamycin: The rapamycin derivative SAR 943 (a macrolide analogue) inhibited ovalbumin-induced IL-4 and IL-5 secretion, cellular influx and fibronectin production, epithelial cell proliferation and mucus hypersecretion in vivo, as well as dosedependently inhibiting in vitro epidermal growth factor-induced proliferation of primary cultured human airway smooth muscle cells (125). These multiple effects make SAR 943 potentially attractive in asthma therapy.

Bronchothermoplasty: Bronchothermoplasty is a novel mode of intervention that consists of applying an electric current to segmental and subsegmental bronchi, with the goal of destroying the smooth muscle and, therefore, reducing its capacity to contract. Although further studies are needed to determine the utility of this treatment, it has been shown to alter airway structure in a possibly beneficial way (113). In fact, Cox et al (110) reported a persistent improvement of 2.9 doubling doses for methacholine in a bronchoprovocation test after a oneyear treatment, and improvement in asthma control in moderate to severe asthmatic patients (111-113).

\section{REMODELLING IN ALLERGIC DISEASES IS NOT RESTRICTED TO THE AIRWAYS}

Allergen exposure triggers an inflammatory response in sensitized subjects and is expressed in targeted tissues such as nasal mucosa, skin and airway mucosa. Allergic rhinitis, atopic dermatitis and asthma share many pathological features. In fact, the same profile of inflammation, mediators and adhesion molecules are observed in upper and lower allergic airway diseases as well as in allergic skin disease. There is a common cellular inflammation pattern characterized by eosinophil, mast cell and $\mathrm{CD}^{+} \mathrm{T}$ cell influx $(126,127)$. Mediators, including histamine, CysLTs, IL-4, IL-5, IL-13, RANTES (regulated on activation, normal T cell expressed and secreted) proteins, and eotaxin are expressed in both upper and lower airways $(128,129)$. Although the initial inflammation induced by allergens is similar in upper and lower airways, the long-term structural consequences differ. In allergic rhinitis, minimal epithelial shedding is observed, with a subsequently smaller degree of basement membrane thickening (130). Atopic dermatitis is also characterized by remodelling, with increased expression of profibrotic cytokines (including TGFbeta, IL-11 and IL-17) and increased subepithelial deposition of collagen (131). Remodelling is observed in all atopic diseases, reinforcing the hypothesis that remodelling is a process driven by inflammation.

\section{CONCLUSION}

Features of airway remodelling include subepithelial fibrosis, an elevated number and volume of mucous cells in the epithelium, increased amounts of airway smooth muscle and increased vascularization of the airway wall. Remodelling of structural and functional tissues in the lungs is a significant morbidity risk factor in individuals with chronic asthma. Clearly, it is important to understand the etiology of airway remodelling in asthma to develop therapies that arrest or reverse it. The concern that asthma is associated with airway remodelling and loss of pulmonary function should prompt clinicians to consider early recognition and intervention. Currently, ICS form the basis of asthma therapy. They are effective anti-inflammatory agents; however, their effects on remodelling and chronic structural changes in the airways are only beginning to be understood. The potential role of antileukotrienes to modulate airway remodelling needs further investigation and more human studies. This is why new treatments should be directed not only against inflammation itself, but also against chronic changes in the lungs of asthmatic patients.

ACKNOWLEDGEMENTS: Dr Celine Bergeron is a recipient of The Research Centre of the University of Montreal Hospital and the young investigator program of the Health Respiratory Network of the Fonds de la recherche en sante Quebec. Dr Meri K Tulic is supported by the Peter Doherty Fellowship from the National Health and Medical Research Council of Australia. This study was supported by an unrestricted grant from Merck Frosst Canada Ltd.

\section{REFERENCES}

1. Redington AE, Howarth PH. Airway wall remodelling in asthma. Thorax 1997;52:310-2.

2. James AL, Maxwell PS, Pearce-Pinto G, Elliot JG, Carroll NG. The relationship of reticular basement membrane thickness to airway wall remodeling in asthma. Am J Respir Crit Care Med 2002;166:1590-5.

3. Naylor B. The shedding of the mucosa of the bronchial tree in asthma. Thorax 1962;17:69-72.

4. Roche WR, Beasley R, Williams JH, Holgate ST. Subepithelial fibrosis in the bronchi of asthmatics. Lancet 1989;1:520-4.

5. Elias JA, Zhu Z, Chupp G, Homer RJ. Airway remodeling in asthma. J Clin Investig 1999;104:1001-6.

6. Carroll N, Elliot J, Morton A, James A. The structure of large and small airways in nonfatal and fatal asthma. Am Rev Respir Dis 1993;147:405-10.

7. Aikawa T, Shimura S, Sasaki H, Ebina M, Takishima T. Marked goblet cell hyperplasia with mucus accumulation in the airways of patients who died of severe acute asthma attack. Chest 1992;101:916-21.

8. Haraguchi M, Shimura S, Shirato K. Morphometric analysis of bronchial cartilage in chronic obstructive pulmonary disease and bronchial asthma. Am J Respir Crit Care Med 1999;159:1005-13.

9. Li X, Wilson JW. Increased vascularity of the bronchial mucosa in mild asthma. Am J Respir Crit Care Med 1997;156:229-33.

10. Tanaka H, Yamada G, Saikai T, et al. Increased airway vascularity in newly diagnosed asthma using a high-magnification bronchovideoscope. Am J Respir Crit Care Med 2003;168:1495-9.

11. Metcalfe DD, Baram D, Mekori YA. Mast cells. Physiol Rev 1997;77:1033-79. 
12. Kroegel C, Virchow JC Jr, Luttmann W, Walker C, Warner JA. Pulmonary immune cells in health and disease: The eosinophil leucocyte (Part I). Eur Respir J 1994;7:519-43.

13. Mosmann TR, Cherwinski H, Bond MW, Giedlin MA, Coffman RL. Two types of murine helper T cell clone. I. Definition according to profiles of lymphokine activities and secreted proteins. J Immunol 1986;136:2348-57.

14. Le Gros G, Ben-Sasson SZ, Seder R, Finkelman FD, Paul WE. Generation of interleukin 4 (IL-4)-producing cells in vivo and in vitro: IL-2 and IL-4 are required for in vitro generation of IL-4-producing cells. J Exp Med 1990;172:921-9.

15. Swain SL, Weinberg AD, English M, Huston G. IL-4 directs the development of Th2-like helper effectors. J Immunol 1990;145:3796-806.

16. Zeiger RS, Dawson C, Weiss S. Relationships between duration of asthma and asthma severity among children in the Childhood Asthma Management Program (CAMP). J Allergy Clin Immunol 1999;103:376-87.

17. Boulet LP, Laviolette M, Turcotte H, et al. Bronchial subepithelial fibrosis correlates with airway responsiveness to methacholine. Chest 1997;112:45-52.

18. Laitinen LA, Heino M, Laitinen A, Kava T, Haahtela T. Damage of the airway epithelium and bronchial reactivity in patients with asthma. Am Rev Respir Dis 1985;131:599-606.

19. Montefort S, Roberts JA, Beasley R, Holgate ST, Roche WR. The site of disruption of the bronchial epithelium in asthmatic and non-asthmatic subjects. Thorax 1992;47:499-503.

20. Ordonez C, Ferrando R, Hyde DM, Wong HH, Fahy JV. Epithelial desquamation in asthma: Artifact or pathology? Am J Respir Crit Care Med 2000;162:2324-9.

21. Shebani E, Shahana S, Janson C, Roomans GM. Attachment of columnar airway epithelial cells in asthma. Tissue Cell 2005;37:145-52.

22. Hackett TL, Knight DA. The role of epithelial injury and repair in the origins of asthma. Curr Opin Allergy Clin Immunol 2007;7:63-8,

23. Jeffery PK, Wardlaw AJ, Nelson FC, Collins JV, Kay AB. Bronchial biopsies in asthma. An ultrastructural, quantitative study and correlation with hyperreactivity. Am Rev Respir Dis 1989;140:1745-53

24. Chakir J, Laviolette M, Boutet M, Laliberte R, Dube J, Boulet LP. Lower airways remodeling in nonasthmatic subjects with allergic rhinitis. Lab Invest 1996;75:735-44.

25. Milanese M, Crimi E, Scordamaglia A, et al. On the functional consequences of bronchial basement membrane thickening. J Appl Physiol 2001;91:1035-40.

26. Payne DN, Rogers AV, Adelroth E, et al. Early thickening of the reticular basement membrane in children with difficult asthma. Am J Respir Crit Care Med 2003;167:78-82.

27. Jenkins HA, Cool C, Szefler SJ, et al. Histopathology of severe childhood asthma: A case series. Chest 2003;124:32-41.

28. Huang J, Olivenstein R, Taha R, Hamid Q, Ludwig M. Enhanced proteoglycan deposition in the airway wall of atopic asthmatics. Am J Respir Crit Care Med 1999;160:725-9.

29. Laitinen A, Altraja A, Kampe M, Linden M, Virtanen I, Laitinen LA. Tenascin is increased in airway basement membrane of asthmatics and decreased by an inhaled steroid. Am J Respir Crit Care Med 1997;156:951-8.

30. Wilson JW, Li X. The measurement of reticular basement membrane and submucosal collagen in the asthmatic airway. Clin Exp Allergy 1997;27:363-71.

31. Karjalainen EM, Lindqvist A, Laitinen LA, et al. Airway inflammation and basement membrane tenascin in newly diagnosed atopic and nonatopic asthma. Respir Med 2003;97:1045-51.

32. Bergeron C, Page N, Joubert P, Barbeau B, Hamid Q, Chakir J. Regulation of procollagen I (alpha1) by interleukin-4 in human bronchial fibroblasts: A possible role in airway remodelling in asthma. Clin Exp Allergy 2003;33:1389-97.

33. Minshall E, Chakir J, Laviolette M, et al. IL-11 expression is increased in severe asthma: Association with epithelial cells and eosinophils. J Allergy Clin Immunol 2000;105:232-8.

34. Hoshino M, Nakamura Y, Sim JJ. Expression of growth factors and remodelling of the airway wall in bronchial asthma. Thorax 1998;53:21-7.

35. Chetta A, Foresi A, Del Donno M, Bertorelli G, Pesci A, Olivieri D. Airways remodeling is a distinctive feature of asthma and is related to severity of disease. Chest 1997;111:852-7.
36. Little SA, Sproule MW, Cowan MD, et al. High-resolution computed tomographic assessment of airway wall thickness in chronic asthma: Reproducibility and relationship with lung function and severity. Thorax 2002;57:247-53.

37. Westergren-Thorsson G, Chakir J, Lafreniere-Allard MJ, Boulet LP, Tremblay GM. Correlation between airway responsiveness and proteoglycan production by bronchial fibroblasts from normal and asthmatic subjects. Int J Biochem Cell Biol 2002;34:1256-67.

38. Lemjabbar H, Gosset P, Lamblin C, et al. Contribution of $92 \mathrm{kDa}$ gelatinase/type IV collagenase in bronchial inflammation during status asthmaticus. Am J Respir Crit Care Med 1999;159(4 Pt 1):1298-307.

39. Prikk K, Maisi P, Pirila E, et al. Airway obstruction correlates with collagenase-2 (MMP-8) expression and activation in bronchial asthma. Lab Invest 2002;82:1535-45.

40. Vignola AM, Riccobono L, Mirabella A, et al. Sputum metalloproteinase-9/tissue inhibitor of metalloproteinase-1 ratio correlates with airflow obstruction in asthma and chronic bronchitis. Am J Respir Crit Care Med 1998;158:1945-50.

41. Suzuki R, Kato T, Miyazaki Y, et al. Matrix metalloproteinases and tissue inhibitors of matrix metalloproteinases in sputum from patients with bronchial asthma. J Asthma 2001;38:477-84.

42. Wenzel SE, Balzar S, Cundall M, Chu HW. Subepithelial basement membrane immunoreactivity for matrix metalloproteinase 9: Association with asthma severity, neutrophilic inflammation, and wound repair. J Allergy Clin Immunol 2003;111:1345-52.

43. Johnson C, Sung HJ, Lessner SM, Fini ME, Galis ZS. Matrix metalloproteinase- 9 is required for adequate angiogenic revascularization of ischemic tissues. Potential role in capillary branching. Circ Res 2004;94:262-8.

44. Johnson C, Galis ZS. Matrix metalloproteinase-2 and -9 differentially regulate smooth muscle cell migration and cellmediated collagen organization. Arterioscler Thromb Vasc Biol 2004;24;54-60.

45. Johnson S, Knox A. Autocrine production of matrix metalloproteinase-2 is required for human airway smooth muscle proliferation. Am J Physiol 1999;277(6 Pt 1):L1109-17.

46. Cataldo DD, Bettiol J, Noel A, Bartsch P, Foidart JM, Louis R. Matrix metalloproteinase-9, but not tissue inhibitor of matrix metalloproteinase-1, increases in the sputum from allergic asthmatic patients after allergen challenge. Chest 2002;122:1553-9.

47. Johnson PR, Burgess JK. Airway smooth muscle and fibroblasts in the pathogenesis of asthma. Curr Allergy Asthma Rep 2004:4:102-8.

48. Joubert P, Lajoie-Kadoch S, Labonte I, et al. CCR3 expression and function in asthmatic airway smooth muscle cells. J Immunol 2005; 175:2702-8.

49. Panettieri RA Jr. Airway smooth muscle: An immunomodulatory cell. J Allergy Clin Immunol 2002;110(Suppl 6):S269-74.

50. Hakonarson H, Maskeri N, Carter C, Grunstein MM. Regulation of TH1 - and TH2-type cytokine expression and action in atopic asthmatic sensitized airway smooth muscle. J Clin Invest 1999;103:1077-87.

51. Johnson PR. Role of human airway smooth muscle in altered extracellular matrix production in asthma. Clin Exp Pharmacol Physiol 2001;28:233-6.

52. Benayoun L, Druilhe A, Dombret MC, Aubier M, Pretolani M. Airway structural alterations selectively associated with severe asthma. Am J Respir Crit Care Med 2003;167:1360-8.

53. Hoshino M, Takahashi M, Aoike N. Expression of vascular endothelial growth factor, basic fibroblast growth factor, and angiogenin immunoreactivity in asthmatic airways and its relationship to angiogenesis. J Allergy Clin Immunol 2001;107:295-301.

54. Noble PB, Turner DJ, Mitchell HW. Relationship of airway narrowing, compliance, and cartilage in isolated bronchial segments. J Appl Physiol 2002;92:1119-24.

55. Sont JK, Han J, van Krieken JM, et al. Relationship between the inflammatory infiltrate in bronchial biopsy specimens and clinical severity of asthma in patients treated with inhaled steroids. Thorax 1996;51:496-502.

56. Molet S, Hamid Q, Davoine F, et al. IL-17 is increased in asthmatic airways and induces human bronchial fibroblasts to produce cytokines. J Allergy Clin Immunol 2001;108:430-8.

57. Chakir J, Shannon J, Molet S, et al. Airway remodeling-associated mediators in moderate to severe asthma: Effect of steroids on 
TGF-beta, IL-11, IL-17, and type I and type III collagen expression. J Allergy Clin Immunol 2003;111:1293-8.

58. Kunzmann S, Schmidt-Weber C, Zingg JM, et al. Connective tissue growth factor expression is regulated by histamine in lung fibroblasts: Potential role of histamine in airway remodeling. J Allergy Clin Immunol 2007;119:1398-407.

59. Bergeron C, Tulic MK, Hamid Q. Tools used to measure airway remodelling in research. Eur Respir J 2007;29:596-604.

60. Lange P, Parner J, Vestbo J, Schnohr P, Jensen G. A 15-year follow-up study of ventilatory function in adults with asthma. N Engl J Med 1998;339:1194-200.

61. Settipane RJ, Hagy GW, Settipane GA. Long-term risk factors for developing asthma and allergic rhinitis: A 23-year follow-up study of college students. Allergy Proc 1994;15:21-5.

62. Guerra S, Sherrill DL, Martinez FD, Barbee RA. Rhinitis as an independent risk factor for adult-onset asthma. J Allergy Clin Immunol 2002;109:419-25.

63. Leynaert B, Bousquet J, Neukirch C, Liard R, Neukirch F. Perennial rhinitis: An independent risk factor for asthma in nonatopic subjects. Results from the European Community Respiratory Health Survey. J Allergy Clin Immunol 1999;104(2 Pt 1):301-4.

64. Laprise C, Laviolette M, Boutet M, Boulet LP. Asymptomatic airway hyperresponsiveness: Relationships with airway inflammation and remodelling. Eur Respir J 1999;14:63-73.

65. Laprise C, Boulet LP. Airway responsiveness and atopy in families of patients with asthma. Clin Invest Med 1996;19:461-9.

66. Watson WT, Becker AB, Simons FE. Treatment of allergic rhinitis with intranasal corticosteroids in patients with mild asthma: Effect on lower airway responsiveness. J Allergy Clin Immunol 1993;91(1 Pt 1):97-101.

67. Corren J, Adinoff AD, Buchmeier AD, Irvin CG. Nasal beclomethasone prevents the seasonal increase in bronchial responsiveness in patients with allergic rhinitis and asthma. J Allergy Clin Immunol 1992;90:250-6.

68. Wilson AM, Orr LC, Sims EJ, Lipworth BJ. Effects of monotherapy with intra-nasal corticosteroid or combined oral histamine and leukotriene receptor antagonists in seasonal allergic rhinitis. Clin Exp Allergy 2001;31:61-8.

69. Bousquet J, Van Cauwenberge P, Khaltaev N. Allergic rhinitis and its impact on asthma. J Allergy Clin Immunol 2001;108(Suppl 5):S147-334.

70. Walker SM, Pajno GB, Lima MT, Wilson DR, Durham SR. Grass pollen immunotherapy for seasonal rhinitis and asthma: A randomized, controlled trial. J Allergy Clin Immunol 2001;107:87-93.

71. Haahtela T, Jarvinen M, Kava T, et al. Effects of reducing or discontinuing inhaled budesonide in patients with mild asthma. N Engl J Med 1994;331:700-5.

72. Levine SJ, Larivee P, Logun C, Angus CW, Shelhamer JH. Corticosteroids differentially regulate secretion of IL-6, IL-8, and $\mathrm{G}$-CSF by a human bronchial epithelial cell line. Am J Physiol 1993;265(4 Pt 1):L360-8.

73. Dorscheid DR, Wojcik KR, Sun S, Marroquin B, White SR. Apoptosis of airway epithelial cells induced by corticosteroids. Am J Respir Crit Care Med 2001;164(10 Pt 1):1939-47.

74. Sabatini F, Silvestri M, Sale R, et al. Concentration-dependent effects of mometasone furoate and dexamethasone on foetal lung fibroblast functions involved in airway inflammation and remodeling. Pulm Pharmacol Ther 2003;16:287-97.

75. Descalzi D, Folli C, Nicolini G, et al. Anti-proliferative and anti-remodelling effect of beclomethasone dipropionate, formoterol and salbutamol alone or in combination in primary human bronchial fibroblasts. Allergy 2008;63:432-7.

76. Young PG, Skinner SJ, Black PN. Effects of glucocorticoids and beta-adrenoceptor agonists on the proliferation of airway smooth muscle. Eur J Pharmacol 1995;273:137-43.

77. Schramm CM, Grunstein MM. Corticosteroid modulation of $\mathrm{Na}(+)-\mathrm{K}+$ pump-mediated relaxation in maturing airway smooth muscle. Br J Pharmacol 1996;119:807-12.

78. Stewart AG, Fernandes D, Tomlinson PR. The effect of glucocorticoids on proliferation of human cultured airway smooth muscle. Br J Pharmacol 1995;116:3219-26.

79. Laitinen LA, Laitinen A. Inhaled corticosteroid treatment for asthma. Allergy Proc 1995;16:63-6.

80. Jeffery PK. Pathology of asthma. Br Med Bull 1992;48:23-39.

81. Boulet LP, Turcotte H, Laviolette M, et al. Airway hyperresponsiveness, inflammation, and subepithelial collagen deposition in recently diagnosed versus long-standing mild asthma.
Influence of inhaled corticosteroids. Am J Respir Crit Care Med 2000;162:1308-13.

82. Olivieri D, Chetta A, Del Donno M, et al. Effect of short-term treatment with low-dose inhaled fluticasone propionate on airway inflammation and remodeling in mild asthma: A placebo-controlled study. Am J Respir Crit Care Med 1997;155:1864-71.

83. Trigg CJ, Manolitsas ND, Wang J, et al. Placebo-controlled immunopathologic study of four months of inhaled corticosteroids in asthma. Am J Respir Crit Care Med 1994;150:17-22.

84. Hoshino M, Takahashi M, Takai Y, Sim J. Inhaled corticosteroids decrease subepithelial collagen deposition by modulation of the balance between matrix metalloproteinase- 9 and tissue inhibitor of metalloproteinase-1 expression in asthma. J Allergy Clin Immunol 1999;104:356-63.

85. Ward C, Pais M, Bish R, et al. Airway inflammation, basement membrane thickening and bronchial hyperresponsiveness in asthma. Thorax 2002;57:309-16.

86. Sont JK, Willems LN, Bel EH, van Krieken JH, Vandenbroucke JP, Sterk PJ. Clinical control and histopathologic outcome of asthma when using airway hyperresponsiveness as an additional guide to long-term treatment. The AMPUL Study Group. Am J Respir Crit Care Med 1999;159(4 Pt 1):1043-51.

87. Mattos W, Lim S, Russell R, Jatakanon A, Chung KF, Barnes PJ. Matrix metalloproteinase-9 expression in asthma: Effect of asthma severity, allergen challenge, and inhaled corticosteroids. Chest 2002;122:1543-52.

88. Mautino G, Oliver N, Chanez P, Bousquet J, Capony F. Increased release of matrix metalloproteinase- 9 in bronchoalveolar lavage fluid and by alveolar macrophages of asthmatics. Am J Respir Cell Mol Biol 1997;17:583-91.

89. Djukanovic R, Wilson JW, Britten KM, et al. Effect of an inhaled corticosteroid on airway inflammation and symptoms in asthma. Am Rev Respir Dis 1992;145:669-74.

90. Laitinen LA, Laitinen A, Heino M, Haahtela T. Eosinophilic airway inflammation during exacerbation of asthma and its treatment with inhaled corticosteroid. Am Rev Respir Dis 1991;143:423-7.

91. Bentley AM, Hamid Q, Robinson DS, et al. Prednisolone treatment in asthma. Reduction in the numbers of eosinophils, $\mathrm{T}$ cells, tryptase-only positive mast cells, and modulation of IL-4, IL-5, and interferon-gamma cytokine gene expression within the bronchial mucosa. Am J Respir Crit Care Med 1996;153:551-6.

92. Lemiere C, Bai T, Balter M, et al. Adult Asthma Consensus Guidelines Update 2003. Can Respir J 2004;11(Suppl A):9A-18A.

93. Dompeling E, van Schayck CP, Molema J, Folgering H, van Grunsven PM, van Weel C. Inhaled beclomethasone improves the course of asthma and COPD. Eur Respir J 1992;5:945-52.

94. Grol MH, Gerritsen J, Vonk JM, et al. Risk factors for growth and decline of lung function in asthmatic individuals up to age 42 years. A 30-year follow-up study. Am J Respir Crit Care Med 1999;160:1830-7.

95. Selroos O, Pietinalho A, Lofroos AB, Riska H. Effect of early vs late intervention with inhaled corticosteroids in asthma. Chest 1995;108:1228-34.

96. Long-term effects of budesonide or nedocromil in children with asthma. The Childhood Asthma Management Program Research Group. N Engl J Med 2000;343:1054-63.

97. Ragab S, Parikh A, Darby YC, Scadding GK. An open audit of montelukast, a leukotriene receptor antagonist, in nasal polyposis associated with asthma. Clin Exp Allergy 2001;31:1385-91.

98. Leigh R, Vethanayagam D, Yoshida M, et al. Effects of montelukast and budesonide on airway responses and airway inflammation in asthma. Am J Respir Crit Care Med 2002;166:1212-7.

99. Henderson WR Jr, Tang LO, Chu SJ, et al. A role for cysteinyl leukotrienes in airway remodeling in a mouse asthma model. Am J Respir Crit Care Med 2002;165:108-16.

100. Muz MH, Deveci F, Bulut Y, Ilhan N, Yekeler H, Turgut T. The effects of low dose leukotriene receptor antagonist therapy on airway remodeling and cysteinyl leukotriene expression in a mouse asthma model. Exp Mol Med 2006;38:109-18.

101. Kelly MM, Chakir J, Vethanayagam D, et al. Montelukast treatment attenuates the increase in myofibroblasts following low-dose allergen challenge. Chest 2006;130:741-53.

102. Milgrom H, Fick RB Jr, Su JQ, et al. Treatment of allergic asthma with monoclonal anti-IgE antibody. rhuMAb-E25 Study Group. N Engl J Med 1999;341:1966-73. 
103. Djukanovic R, Wilson SJ, Kraft M, et al. Effects of treatment with anti-immunoglobulin $\mathrm{E}$ antibody omalizumab on airway inflammation in allergic asthma. Am J Respir Crit Care Med 2004;170:583-93.

104. Noga O, Hanf G, Kunkel G. Immunological and clinical changes in allergic asthmatics following treatment with omalizumab. Int Arch Allergy Immunol 2003;131:46-52.

105. Orsida BE, Ward C, Li X, et al. Effect of a long-acting beta2-agonist over three months on airway wall vascular remodeling in asthma. Am J Respir Crit Care Med 2001;164:117-21.

106. Kidney J, Dominguez M, Taylor PM, Rose M, Chung KF, Barnes PJ. Immunomodulation by theophylline in asthma. Demonstration by withdrawal of therapy. Am J Respir Crit Care Med 1995;151:1907-14

107. Serebrisky D, Teper AA, Huang CK, et al. CpG oligodeoxynucleotides can reverse Th2-associated allergic airway responses and alter the B7.1/B7.2 expression in a murine model of asthma. J Immunol 2000;165:5906-12.

108. Flood-Page P, Menzies-Gow A, Phipps S, et al. Anti-IL-5 treatment reduces deposition of ECM proteins in the bronchial subepithelial basement membrane of mild atopic asthmatics. J Clin Invest 2003;112:1029-36

109. Billington CK, Joseph SK, Swan C, Scott MG, Jobson TM, Hall IP. Modulation of human airway smooth muscle proliferation by type 3 phosphodiesterase inhibition. Am J Physiol 1999;276:L412-L9.

110. Cox G MJ, McWilliams A, Fitzgerald M, Lam S. Bronchial thermoplasty: One-year update. Am J Respir Crit Care Med 2004:A313.

111. Cox G. New interventions in asthma including bronchial thermoplasty. Curr Opin Pulm Med 2008;14:77-81.

112. Cox G, Thomson NC, Rubin AS, et al. Asthma control during the year after bronchial thermoplasty. N Engl J Med 2007;356:1327-37.

113. Pavord ID, Cox G, Thomson NC, et al. Safety and efficacy of bronchial thermoplasty in symptomatic, severe asthma. Am J Respir Crit Care Med 2007;176:1185-91.

114. Borish LC, Nelson HS, Lanz MJ, et al. Interleukin-4 receptor in moderate atopic asthma. A phase I/II randomized, placebocontrolled trial. Am J Respir Crit Care Med 1999;160:1816-23.

115. Henderson WR Jr, Chi EY, Maliszewski CR. Soluble IL-4 receptor inhibits airway inflammation following allergen challenge in a mouse model of asthma. J Immunol 2000;164:1086-95.

116. Tomkinson A, Duez C, Cieslewicz G, et al. A murine IL-4 receptor antagonist that inhibits IL-4- and IL-13-induced responses prevents antigen-induced airway eosinophilia and airway hyperresponsiveness. J Immunol 2001;166:5792-800.

117. Leckie MJ, ten Brinke A, Khan J, et al. Effects of an interleukin-5 blocking monoclonal antibody on eosinophils, airway hyperresponsiveness, and the late asthmatic response. Lancet 2000;356:2144-8

118. Blyth DI, Wharton TF, Pedrick MS, Savage TJ, Sanjar S. Airway subepithelial fibrosis in a murine model of atopic asthma:
Suppression by dexamethasone or anti-interleukin-5 antibody. Am J Respir Cell Mol Biol 2000;23:241-6.

119. Tulic MK, Fiset PO, Christodoulopoulos P, et al. Amb a 1-immunostimulatory oligodeoxynucleotide conjugate immunotherapy decreases the nasal inflammatory response. J Allergy Clin Immunol 2004;113:235-41.

120. Kline JN, Waldschmidt TJ, Businga TR, et al. Modulation of airway inflammation by $\mathrm{CpG}$ oligodeoxynucleotides in a murine model of asthma. J Immunol 1998;160:2555-9.

121. Jain VV, Kitagaki K, Businga T, et al. CpG-oligodeoxynucleotides inhibit airway remodeling in a murine model of chronic asthma. J Allergy Clin Immunol 2002;110:867-72.

122. Fanucchi MV EM, Baker GL, et al. Immunostimulatory DNA Sequence (ISS) inhibition of airways remodeling in young adult rhesus monkey. Am J Respir Crit Care Med 2003;167:A955.

123. Campos HS, Xisto DG, Oliveira MB, et al. Protective effects of phosphodiesterase inhibitors on lung function and remodeling in a murine model of chronic asthma. Braz J Med Biol Res 2006;39:283-7.

124. Kumar RK, Herbert C, Thomas PS, et al. Inhibition of inflammation and remodeling by roflumilast and dexamethasone in murine chronic asthma. J Pharmacol Exp Ther 2003;307:349-55.

125. Fujitani Y, Trifilieff A. In vivo and in vitro effects of SAR 943, a rapamycin analogue, on airway inflammation and remodeling. Am J Respir Crit Care Med 2003;167:193-8.

126. Bradley BL, Azzawi M, Jacobson M, et al. Eosinophils, T-lymphocytes, mast cells, neutrophils, and macrophages in bronchial biopsy specimens from atopic subjects with asthma: Comparison with biopsy specimens from atopic subjects without asthma and normal control subjects and relationship to bronchial hyperresponsiveness. J Allergy Clin Immunol 1991;88:661-74.

127. Varga EM, Jacobson MR, Till SJ, et al. Cellular infiltration and cytokine mRNA expression in perennial allergic rhinitis. Allergy 1999;54:338-45.

128. KleinJan A, Dijkstra MD, Boks SS, Severijnen LA, Mulder PG Fokkens WJ. Increase in IL-8, IL-10, IL-13, and RANTES mRNA levels (in situ hybridization) in the nasal mucosa after nasal allergen provocation. J Allergy Clin Immunol 1999;103(3 Pt 1):441-50.

129. Nag S, Lamkhioued B, Renzi PM. Interleukin-2-induced increased airway responsiveness and lung Th2 cytokine expression occur after antigen challenge through the leukotriene pathway. Am J Respir Crit Care Med 2002;165:1540-5.

130. Bousquet J, Jacquot W, Vignola AM, Bachert C, Van Cauwenberge P. Allergic rhinitis: A disease remodeling the upper airways? J Allergy Clin Immunol 2004;113:43-9.

131. Toda M, Leung DY, Molet S, et al. Polarized in vivo expression of IL-11 and IL-17 between acute and chronic skin lesions. J Allergy Clin Immunol 2003;111:875-81.

132. Minshall EM, Leung DY, Martin RJ, et al. Eosinophil-associated TGF-beta1 mRNA expression and airways fibrosis in bronchial asthma. Am J Respir Cell Mol Biol 1997;17:326-33. 


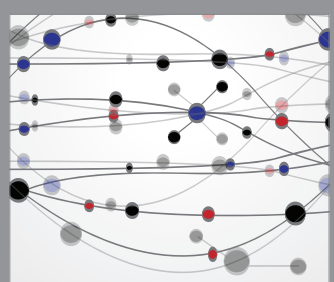

The Scientific World Journal
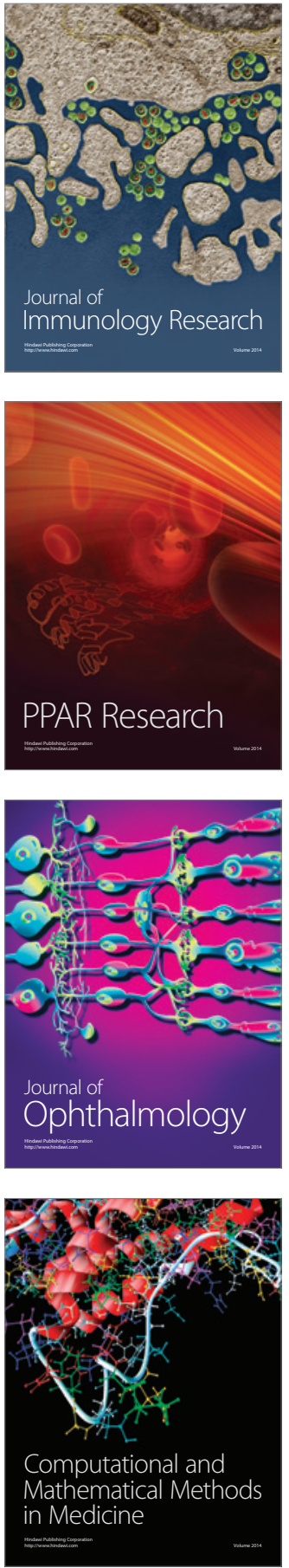

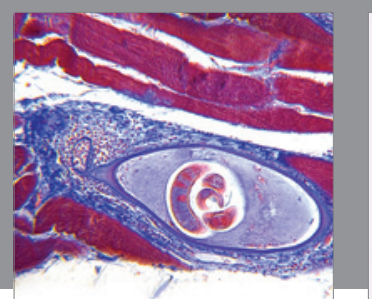

Gastroenterology Research and Practice

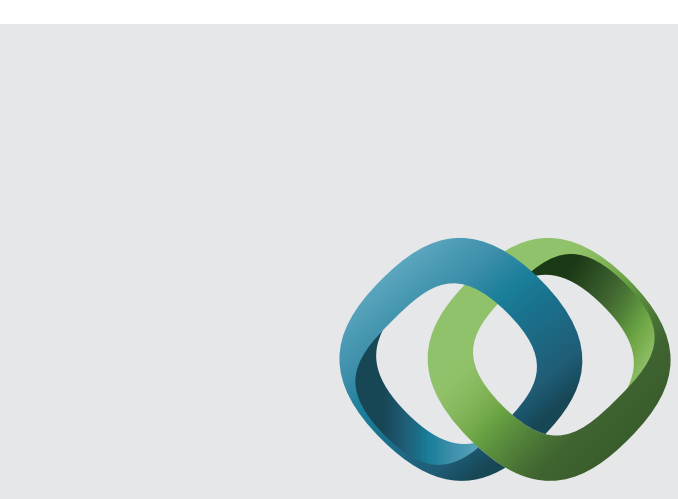

\section{Hindawi}

Submit your manuscripts at

http://www.hindawi.com
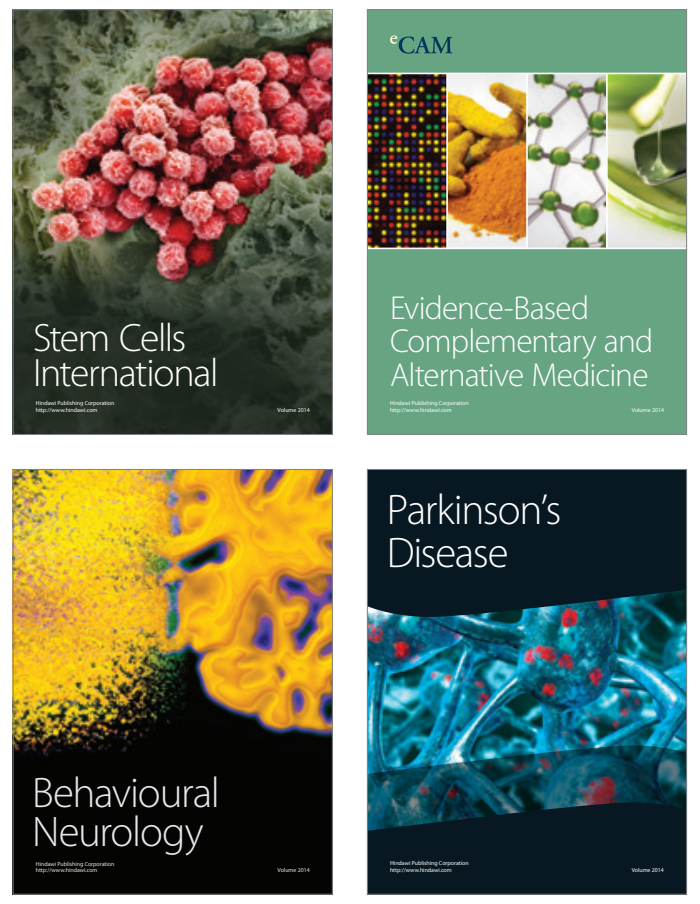
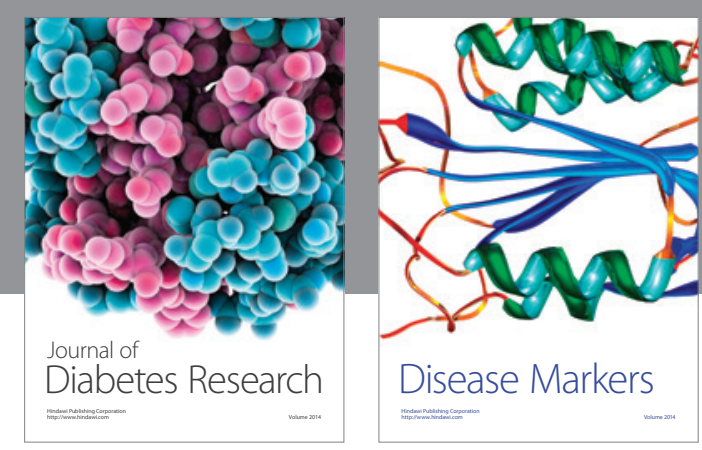

Disease Markers
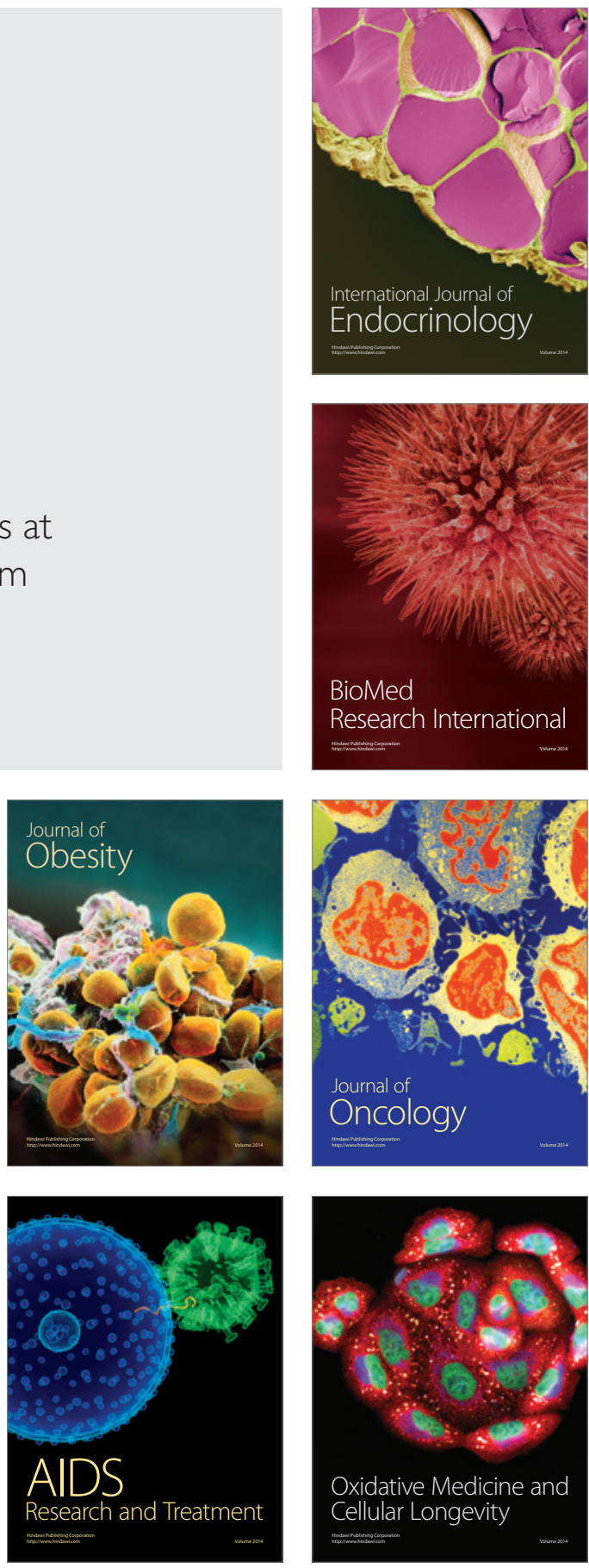